\title{
BUSINESS MODELS ALONG SUPPLY CHAIN POSITION AND SERVITISATION: AN EMPIRICAL INVESTIGATION OF EUROPEAN MANUFACTURERS*
}

\author{
Levente SZÁSZ - Krisztina DEMETER \\ (Received: 15 January 2014; revision received: 21 June 2014; \\ accepted: 10 July 2014)
}

Competitive pressures of the world economy are continuously reshaping the global supply chains of manufacturing firms. At the same time, global competition is altering the nature of output offered by manufacturers, shifting it towards a higher share of service elements. The goal of this paper is to investigate how these two factors are combined, using a sample of manufacturing companies from 13 European countries belonging to the assembly industries of fabricated metal products, machinery and equipment. The results indicate that different business models became dominant in the less developed Eastern European and the developed Western European region. Involving measures of business performance and reasons for plant location, this study also argues that in terms of service offerings and supply chain position, other types of business models can coexist and successfully prevail in the two regions.

Keywords: internationalisation, outsourcing/offshoring, supply chain, servitisation, business models

JEL classification indices: C42, F29, L60, M11

* This research was supported by the Domus Hungarica scholarship of the Hungarian Academy of Sciences (DM/76/2012).

Levente Szász, Associate Professor at the Faculty of Economics and Business Administration, Department of Economics and Business Administration in Hungarian Language, Babeş-Bolyai University, Cluj-Napoca, Romania.

E-mail: levente.szasz@econ.ubbcluj.ro

Krisztina Demeter, corresponding author. Professor at the Institute of Business Economics, Logistics and Supply Chain Management Department, Corvinus University of Budapest.

E-mail: krisztina.demeter@uni-corvinus.hu 


\section{INTRODUCTION}

During the past few decades, the globalisation of the world economy has fundamentally changed the way economies function and firms operate. This global pressure has driven, and continues to drive - although with changing dynamics manufacturers to internationalise and outsource production activities (e.g. Sideri 1997; Levy 2005; Kinkel 2012). At the same time, global competition forces manufacturers to modify their key outputs from being exclusively physical towards being more "intellectual", intangible, and knowledge intensive (Mudambi 2008).

Thus, on the one hand, increasing global competitive pressure forces individual firms to search for new sources of competitive advantage, either through import-export activities, or through establishing foreign manufacturing facilities (Shi 2003). By import-export activities, they can get access to more advantageous sourcing and selling markets, while by establishing foreign production units, they can exploit low cost factors, or establish direct access to important markets, skills, and knowledge (Ferdows 1997). By this internationalisation, and particularly by outsourcing and offshoring production activities, the supply chain structure and position of these companies may change radically, where the coordination of supply chain activities becomes a central issue.

On the other hand, global competition has also led to a change in the nature of outputs. In order to remain competitive, manufacturing firms have to offer solutions, i.e. bundles of goods and services, rather than just physical products (Davies et al. 2006). The gradual shift of manufacturing companies towards incorporating more and more services into their core offering is termed servitisation in the literature (Baines et al. 2009), a concept introduced by Vandermerwe - Rada (1988). Main drivers of servitisation include the fact that services are able to generate higher and more stable flows of revenue, generally coupled with higher profit margins (Wise - Baumgartner 1999). Furthermore, services can be used for selling more products since they add value to the core product and are able to create customer loyalty (Gebauer - Fleisch 2007; Correa et al. 2007). Scholars also agree that due to increasing global competition, traditional product based competitive advantages are almost impossible to sustain, while services can still represent a differentiating factor between manufacturing companies (Frambach et al. 1997; Gebauer - Fleisch 2007).

Altogether, global competition influences both the supply chain structure and the servitisation level of manufacturing companies. The literature is rich in research on both supply chain structures (Melo et al. 2009) and the servitisation of manufacturing (Baines et al. 2009). The combination of the two areas, however, has rarely been investigated. Our paper aims to fill this gap in the literature. Both 
relocating supply chain activities and adding service elements to the core product seem to be a dominant trend of today's businesses. However, for individual firms, it is still a crucially important question to what extent to follow these trends, and how to combine supply chain- and servitisation-related strategies most efficiently. The aim of this paper is to identify relevant business models in Europe in terms of servitisation and supply chain position. It is not the purpose of the paper to develop a guide on how to combine supply chain and servitisation decisions, but rather to map and explore existing business models based on a sample of European manufacturing plants.

In order to reach the purpose of this paper, the next section briefly reviews the relevant literature, establishing a theoretical connection between the internationalisation of production in terms of evolving supply chain structures and the servitisation of manufacturing firms. Research questions are formulated based on the literature, specifically focusing on the contrast between Eastern and Western European manufacturing. Then, in Section 3, we present the research design and methodology, including the database used in our empirical research and the variables developed. Section 4 presents the results of our analysis, discussing them from the perspective of the formulated research questions. The last section of the paper contains our conclusions and possibilities for further research.

\section{LITERATURE REVIEW AND RESEARCH QUESTIONS}

The global pattern of the internationalisation of production activities (Sideri 1997; UNCTAD 2013) applies in the case of European manufacturers too. After the fall of socialist regimes in Eastern Europe, Western European companies started to offshore and outsource their production processes to this region. Thus, a new division of labour has been developed, in which most Eastern European manufacturing companies became the suppliers of their Western European counterparts (Marin 2006). The enlargement of the European Union in 2004, when 10 new -8 of them Eastern European - countries accessed the community, further strengthened this process (Eckert - Rossmeissl 2005; Garmel et al. 2008; Filippov - Duysters 2011). Based on empirical data, a study of the European Manufacturing Survey also showed that a large proportion of Western European manufacturing companies have parts of their production processes offshored abroad, and one of the main target regions are the emerging markets of Eastern Europe. At the same time, production offshoring is rather uncommon in Eastern Europe (Dachs et al. 2006). Similarly, in a study of 105 subsidiaries located in three Eastern European countries (Hungary, Lithuania, and Poland), Yang et al. (2008) found that their headquarters were mostly located in Western Europe. 
Referring to the contrast between developed and emerging regions, Mudambi (2008) argues that while low value-adding and repetitive manufacturing processes are frequently relocated to developing regions, high value-adding downstream activities generally remain in the home country. Indeed, in a previous comparative study of the developing Eastern European and the more developed Western European regions, the authors found that, on average, Western European manufacturers occupy a more downstream position in the supply chain than their Eastern European counterparts. Moreover, that study seems to confirm that the difference is largely caused by Eastern European companies that perform repetitive, upstream manufacturing activities more frequently (Szász - Demeter 2011).

Based on a similar logic, since after-sales services represent high value-adding downstream activities (Mudambi 2008), they should also be more representative for manufacturing companies from Western Europe. The literature often describes a general pattern of servitisation as a process starting with the outsourcing of upstream, low value-adding production processes, followed by a downstream integration in the supply chain, which facilitates a greater focus on customer-oriented service offerings (Davies 2004). Szász - Demeter (2011) have also shown that while the level of product-related service offering is similar in the two European regions, Western European manufacturers place a significantly higher emphasis on offering customer-related services.

Consequently, international research offers a solid support for both the globalisation-supply chain structure, and the globalisation-servitisation link. Our paper focuses on the combination of supply chain position and servitisation issues, an area that has not yet been fully explored in the scientific literature (Baines et al. 2011). The research context is illustrated in Figure 1, where the arrow with the dashed line marks the relationship investigated.

While there are some case studies that suggest that there is a connection between the change of supply chain position and the servitisation of manufacturing (e.g. Oliva - Kallenberg 2003; Cohen et al. 2006), empirical investigations are quite scarce (Bikfalvi et al. 2013). Focusing on European manufacturing plants, this paper aims to identify relevant business models in terms of existing combinations of different supply chain positions and different levels of customerrelated service offerings. These two characteristics have previously been found to significantly differ between the Eastern and Western European regions (Szász Demeter 2011), but the possible combinations of these two items on individual plant level have not yet been investigated. Thus, we formulate our first research question as follows.

RQ1: What are the viable combinations of supply chain position and customerrelated service offering in Eastern and Western European manufacturing plants? 


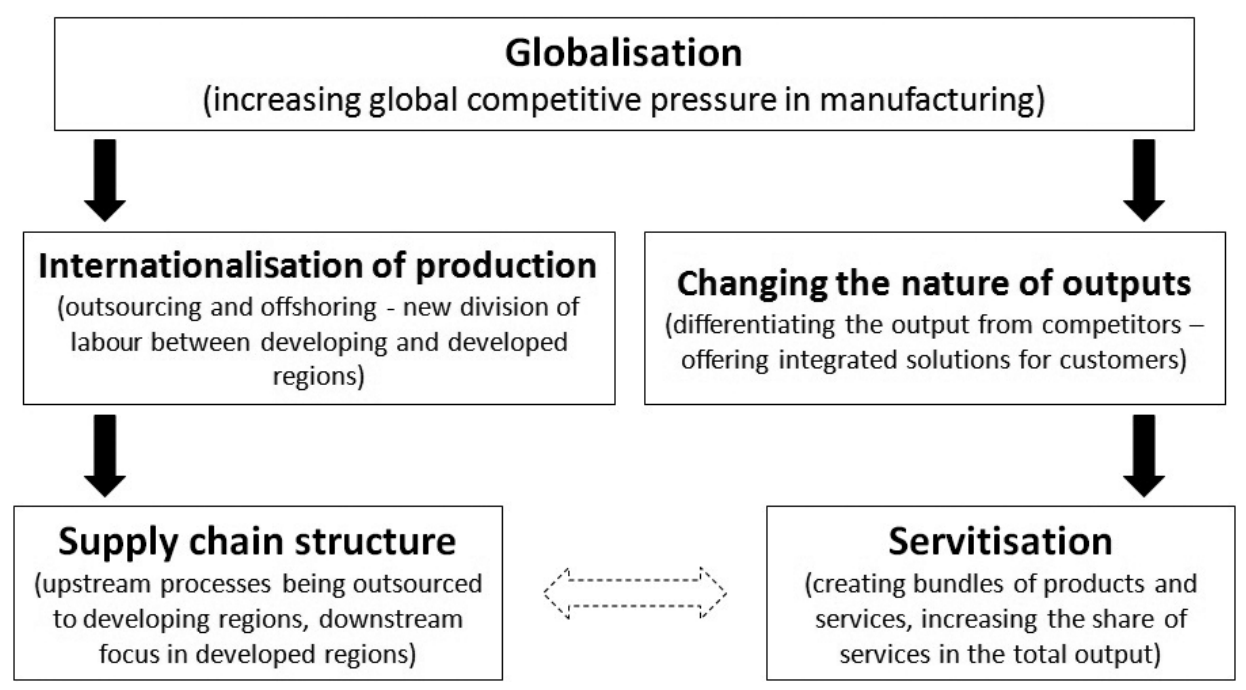

Figure 1. Research framework

While the previous literature suggests that a more downstream supply chain position and a higher level of servitisation should be the typical pattern in Western Europe, and a more upstream position coupled with a lower stage of servitisation in Eastern Europe, we argue that the presence and possible success of other business models should not be excluded either. Thus, our study also aims to investigate the reasons behind operating different business models and their sustainability in terms of achieved business performances.

RQ2: What are the reasons behind the existence of different business models in Eastern and Western Europe, and how successful are they?

\section{RESEARCH DESIGN AND METHODOLOGY}

This research uses data from the fifth round of the International Manufacturing Strategy Survey (IMSS V, www.manufacturingstrategy.net). The sample used in this paper covers a total of 445 manufacturing companies from 13 European countries (see Table 1). All firms belong to the ISIC Rev. 3.1 Division 28-35 sectors (see Table 2). IMSS V was carried out in 2009-2010 by an international network of researchers focusing on manufacturing strategies, practices, and performance of industrial companies from all around the world. Targeted companies included the best performing manufacturers in the previously mentioned industrial sectors, 
being selected from country level official databases. The data collection process was administered by local coordinators in each country and, where needed, the English language questionnaire was translated by manufacturing strategy academics. Questionnaires were completed by Manufacturing/Operations Managers or the person with an equivalent position in the company. The response rate for the European sample was $23.2 \%$. For the purpose of this research, companies from the European sample were grouped into two categories: firms operating in developed economies from Western Europe and those operating in developing economies from Eastern Europe. The rationale behind using these two regions as the unit of analysis is that differences in the level of economic development are clearly distinguishable, and each group of countries represents a relatively homogeneous cultural block (Ronen - Shenkar 1985). Several studies on internationalisation have proved the reliability of regions and cultural blocks as a unit of analysis (Barkema - Drogendijk 2007; Poór et al. 2009). Table 1 presents the IMSS V sample composition by European countries and regions. In respect of size, the European companies included in the study had 1237 employees on average. Table 2 presents the composition of the European sample by industry, while Table 3 presents the distribution by size.

Items of the questionnaire used for investigating the characteristics of the supply chain position, the level of servitisation, the business performance, and the reasons behind plant location of European manufacturing companies are presented in Appendix A.

To determine the supply chain position of manufacturing companies we used a methodology developed in Szász - Demeter (2011). First, an upstream and a downstream position measure were developed based on the questionnaire items presented in Appendix A.1. Then, a supply chain position $(S c P o s)$ and a vertical integration (VertInt) measure was created. The measure of the overall supply chain position is based on two components: the developed UpstreamPos indicator measures to what extent a company positions itself upstream in the supply chain, while DownstreamPos describes to what extent a company is positioned downstream in the supply chain (both having a value between 0 , the lowest, and 1 , the highest up/downstream position). The difference between these two measures offers a good indicator of the overall supply chain position of a company. ScPos $=0$ means that downstream and upstream positions are similar. $S c P o s>0$ means an upstream declination, while $\mathrm{ScPos}<0$ means a downstream declination. On the other hand, the sum of the upstream and downstream measures provides an indication of the extent of the vertical integration of a company. The higher the value of VertInt, the more manufacturing processes the company embraces.

In order to gain a detailed picture about the level of servitisation of manufacturing companies, the six different types of services (see Appendix A.2) were 
grouped into two categories: product-related services and customer-related services. The literature suggests that the process of servitisation generally starts with the supply of product-related services, and at a higher stage it evolves to incorporating customer-related services into the key offering of the company (Oliva - Kallenberg 2003; Gebauer et al. 2005). Therefore, it is also important to assess the kind of services supplied. Consequently, we developed an indicator of product-related service offerings (ProdRelServ), which includes maintenance, product upgrades, repairs, and spare-parts (Cronbach's alpha $=.820$ ), and an indicator for customer-related service offerings (CustRelServ), including measures of help desk, customer support centre, and training (Cronbach's alpha $=.806$ ).

Table 1

Sample by countries

\begin{tabular}{|l|c|l|c|l|c|}
\hline \multicolumn{5}{|c|}{ Western Europe } & \multicolumn{2}{c|}{ Eastern Europe } \\
\hline Belgium & $\begin{array}{c}\text { No. of } \\
\text { companies }\end{array}$ & \multicolumn{1}{|c|}{ Country } & $\begin{array}{c}\text { No. of } \\
\text { companies }\end{array}$ & \multicolumn{1}{c|}{ Country } & $\begin{array}{c}\text { No. of } \\
\text { companies }\end{array}$ \\
\hline Denmark & 36 & Netherlands & 51 & Estonia & 27 \\
\hline Germany & 18 & Portugal & 10 & Hungary & 71 \\
\hline Ireland & 68 & Spain & 40 & Romania & 31 \\
\hline Italy & 56 & Switzerland & 31 & & \\
\hline TOTAL & UK & 30 & & 129 \\
\hline
\end{tabular}

Table 2

Sample by industry

\begin{tabular}{|c|c|}
\hline $\begin{array}{l}\text { ISIC code } \\
\text { (Rev. 3.1) }\end{array}$ & No. of companies, and (\%) \\
\hline 28 & $170(38.2 \%)$ \\
\hline $29-30$ & $120(27.0 \%)$ \\
\hline $31-32$ & $78(17.5 \%)$ \\
\hline 33 & $27(6.1 \%)$ \\
\hline $34-35$ & $45(10.1 \%)$ \\
\hline
\end{tabular}

ISIC Rev. 3.1: 28 - Manufacture of fabricated metal products, except machinery and equipment; 29 - Manufacture of machinery and equipment not classified elsewhere; 30 - Manufacture of office, accounting, and computing machinery; 31 - Manufacture of electrical machinery and apparatus not classified elsewhere; 32 - Manufacture of radio, television, and communication equipment and apparatus; 33 - Manufacture of medical, precision and optical instruments, and watches and clocks; 34 - Manufacture of motor vehicles, trailers, and semi-trailers; 35 - Manufacture of other transport equipment
Table 3

Sample by size

\begin{tabular}{|l|c|}
\hline Size & No. of companies, and (\%) \\
\hline Small & $235(52.8 \%)$ \\
\hline Medium & $96(21.6 \%)$ \\
\hline Large & $112(25.2 \%)$ \\
\hline
\end{tabular}

Small: 50-250 employees; Medium: 251-500 employees; Large: over 500 employees ( 2 missing values $-0.4 \%$ ) 


\section{DATA ANALYSIS AND DISCUSSION}

\subsection{The division of labour between Eastern and Western Europe - distinctive business models elements}

Before exploring $R Q 1$, we investigated whether the general division of labour between Western and Eastern European manufacturing can be confirmed in our sample too. Indeed, $41.7 \%$ of the Western European manufacturing companies from our sample have already established production facilities abroad, while the same figure in Eastern Europe is only 12.7\%. The general effort undertaken to internationalise production is also significantly higher $(A N O V A, F(1,396)=$ 19.176, $p=.000$ ) in Western Europe (mean $=2.18$, measured on a 5-point Likert scale) than in Eastern Europe (mean = 1.59). In concordance with these findings, Szász - Demeter (2011) used the same sample of European manufacturers to show that the division of labour between the two regions has led to a more downstream supply chain position of Western European manufacturers. Focusing more on downstream activities, Western European manufacturers also offer customer-related services more intensively. The main distinctive features of Western and Eastern European manufacturers, on an aggregate level, are summarised in Table 4.

Table 4

Distinctive business model elements in Western and Eastern European manufacturing

\begin{tabular}{|l|c|c|}
\hline & Western Europe & Eastern Europe \\
\hline Production outsourcing/offshoring & Higher & Lower \\
\hline Supply chain position & More downstream & More upstream \\
\hline Customer-related service offerings & Higher & Lower \\
\hline
\end{tabular}

\subsection{Identifying business models in Eastern and Western Europe}

To explore $R Q 1$, we developed a $2 \times 2$ matrix to distinguish manufacturing companies in respect of the two factors (supply chain position, customer-related services) which have been shown to significantly differ between Eastern and Western Europe (Table 4):

1. Supply chain position: to distinguish between more upstream and more downstream supply chain positions, first a hierarchical cluster analysis with Ward's method and squared Euclidean distance measure was performed. Results indicated that the two-cluster solution is reliable, which also conforms to our 
logic of distinguishing between upstream and downstream positions. Next, a k-means cluster analysis was carried out with 2 clusters. Results for the whole European sample are shown in Table 5.

Table 5

Groups of firms based on supply chain position (scale: $-1 . .+1$ )

\begin{tabular}{|l|c|c|c|}
\hline & Mean(ScPos) & $\operatorname{Min}(\mathrm{ScPos})$ & $\operatorname{Max}(\mathrm{ScPos})$ \\
\hline Upstream group & 0.4532 & 0.13 & 1.00 \\
\hline Downstream group & -0.2040 & -0.92 & 0.12 \\
\hline
\end{tabular}

2. Customer-related service offering: is used to distinguish between firms that have arrived at a higher stage of servitisation by intensively offering customer-oriented services, and those that have not. Since customer-related services were measured on a 5-point Likert scale, those who scored at least 3 on average (CustRelServ $\geq 3$ ) were considered as highly servitised.

These two criteria were used to develop the four categories of the matrix (Upstream Manufacturer - UM, Downstream Manufacturer - DM, Upstream Partner - UP, Customer-focused Downstream Manufacturer - CDM), as shown in Figure 2. Then, each European manufacturing company from our sample (a total of 377 companies with valid data) was classified into one of the four categories of the matrix. Figure 2 summarises the results, also indicating the percentage of companies from each region falling into one of the four categories of the matrix, while the numbers in parentheses indicate the exact number of companies in each category.

As it is shown in Figure 2, in Western Europe the dominant business model is the Customer-focused Downstream Manufacturer (CDM). However, almost 30\% of the Western European companies fall into the exactly opposite category (Upstream Manufacturer, UM), which indicates that other business models could also be viable. The same logic applies for Eastern Europe, where the dominant business model accounts for "only" $38 \%$ of the Eastern European sample. Thus, our results show that multiple business models can coexist in both European regions.

\subsection{Exploring business models in Eastern and Western Europe}

To explore $R Q 2$ and to have a more detailed picture about the way different business models function and the performances they can achieve in both regions, the following measures were included in our analysis: upstream and downstream 


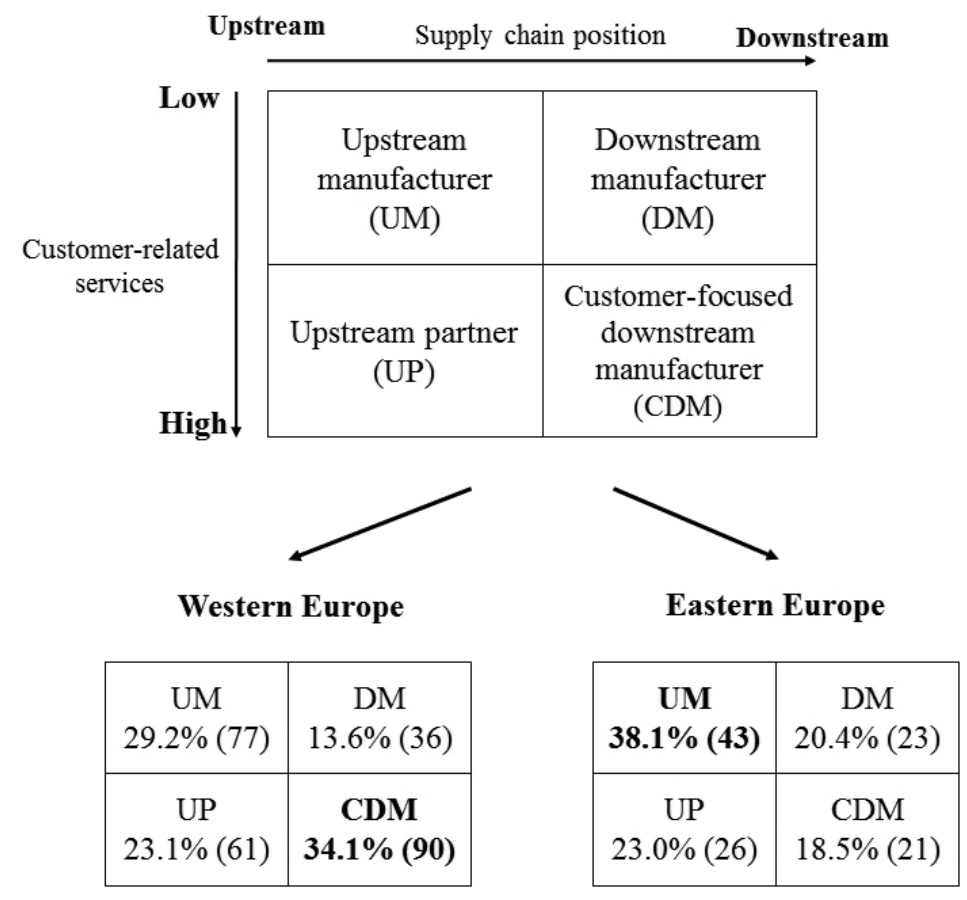

Figure 2. Classification of companies by supply chain position and customer-related service offering

position measures (Appendix A.1), business performance indicators (Appendix A.3), advantages offered by the location of the plant (Appendix A.4), the degree of vertical integration, and the extent of product-related service offerings (ProdRelServ). Variance analysis (ANOVA) and Scheffe post-hoc test was used to determine differences between each pair of the four categories of the matrix.

\subsubsection{Characteristics of business models in Western Europe}

In the following two subsections, greater-than $(>)$ and less-than signs $(<)$ indicate that there is a significant difference between two different business models (Scheffe-test, $p<0.05$ ), thus enabling us to establish a clear order of business models in respect of the indicators involved in our study. Equal sign $(=)$ is used to express that there are no significant differences between a pair of categories. The main characteristics of Western European business models are summarised in Figure 3. Appendix B contains the detailed results. 


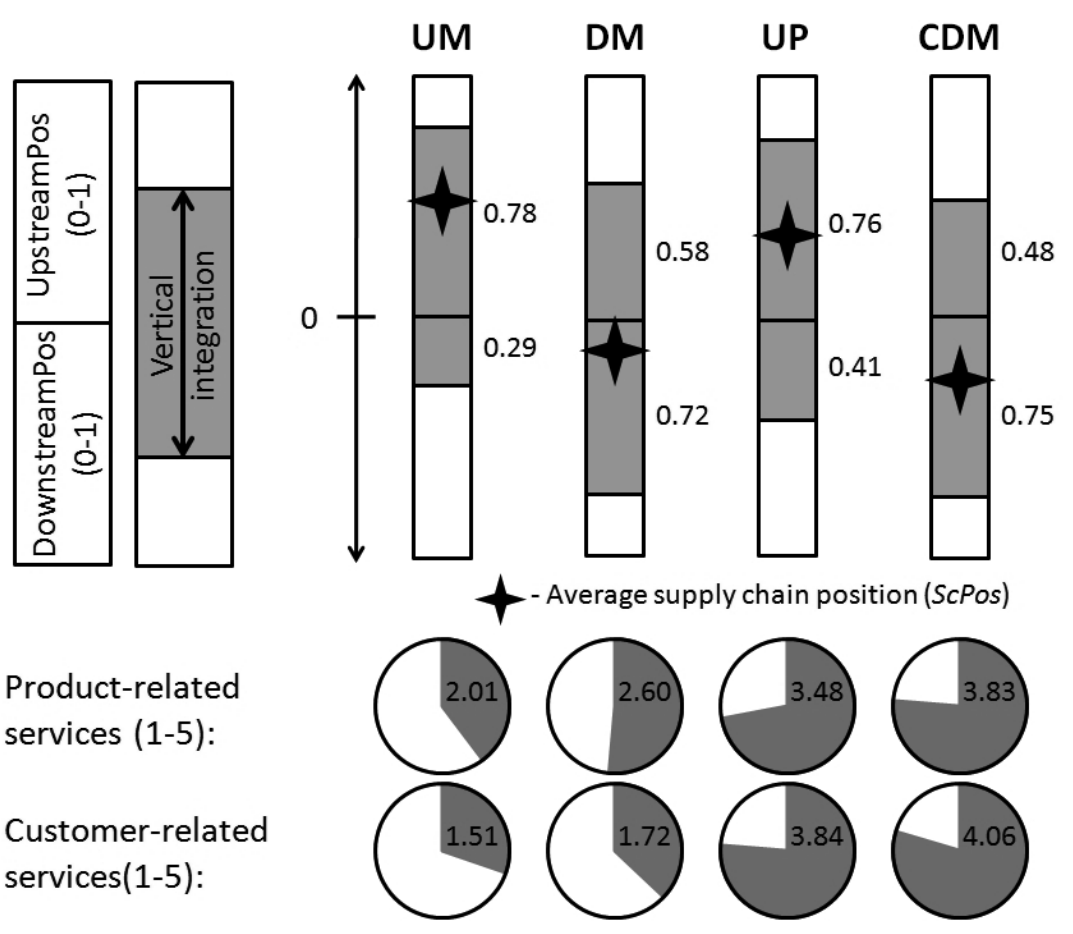

Figure 3. The main characteristics of Western European business models

After comparing each pair of categories from the matrix, the following order was established in respect of upstream and downstream measures.

Upstream position: $\mathrm{CDM}<\mathrm{DM}<\mathrm{UM}=\mathrm{UP}$

Downstream position: $\mathrm{UM}<\mathrm{UP}<\mathrm{DM}=\mathrm{CDM}$

While upstream business models (UM, UP) were expected to have higher upstream values and lower downstream values than downstream business models (DM, CDM), some interesting results are also to be found. The CDM model has a significantly lower upstream position relative to the DM model, which indicates that, in Western Europe, in order to be able to clearly focus on customerrelated service offerings, manufacturers have to intensively outsource upstream production processes and to rely extensively on supplier firms. An analogous logic applies to the upstream part of the supply chain. The UM model has a lower downstream score than the UP. That is, if an upstream manufacturer wants to make the move towards higher levels of servitisation, it needs to integrate more 
downstream processes. On the other hand, the UM model represents specialised upstream manufacturers controlling only a narrow niche of the chain of production activities as indicated by the vertical integration measure (VertInt).

Vertical integration: $\mathrm{UM}<\mathrm{DM}=\mathrm{CDM}$ (while $\mathrm{UM}=\mathrm{UP}$ and $\mathrm{UP}=\mathrm{DM}$ ) In respect of product-related services, the following order was established:

$$
\text { Product-related services: } \mathrm{UM}<\mathrm{DM}<\mathrm{UP}=\mathrm{CDM}
$$

UM has the lowest intensity of product-related service offerings, further strengthening the image of a specialised, niche manufacturer. However, making a move toward downstream integration (DM), or entering a customer-focused service business, requires higher and higher levels of product-related services. Thus, entering more downstream or more intensively servitised businesses, productrelated services take the role of a kind of entry pass. This result also confirms case study findings suggesting that the process of servitisation starts with offering product-related services, and at later stages it advances towards offering more sophisticated customer-focused services (Oliva - Kallenberg 2003; Gebauer et al. 2005). These findings also show that - despite the fact that the servitisation literature focuses mainly on the opportunities of downstream players (OEMs) to create substantial value added by offering services alongside products (Wise Baumgartner 1999; Lay et al. 2010) - upstream players may also benefit from the same opportunities (i.e. the UP business model). Our results show that additional value stemming from service provision can be captured both in upstream and downstream supply chain positions.

Another facet of the supply chain position is the advantage offered by the location of the manufacturing unit, which can give a hint about the reason behind the existence of different business models. Here, the CDM category receives low scores on low-cost-related factors:

Low-cost material: $\mathrm{CDM}<\mathrm{DM}$ (while $\mathrm{CDM}=\mathrm{UP}=\mathrm{UM}$ and $\mathrm{UP}=\mathrm{UM}=\mathrm{DM}$ )

Low-cost labour (significance level of $p<0.1$ ): $\mathrm{CDM}<\mathrm{DM}=\mathrm{UP}=\mathrm{UM}$

This suggests that moving downstream towards end-users and advancing towards a larger share of customer-related services in the output portfolio should not be grounded on low-cost competitive factors. Services add important value to the core offering of the company, and therefore they can be sold at higher prices (Correa et al. 2007; Gebauer - Fleisch 2007). The basis of competition between these firms moves away from price-based factors toward service-related factors (Demeter - Szász 2013). 
Lastly, after examining business performances of different business models, only very few significant differences were found. Upstream business models had the lowest performance in terms of return on sales (ROS) compared to main competitors (UP $<\mathrm{DM}$ and $\mathrm{UM}<\mathrm{DM}$ ). These results suggest that upstream activities have a lower profitability in Western Europe, which is in concordance with the internationalisation literature. This can be one reason for Western European manufacturers to relocate their upstream processes to developed countries with significantly lower costs (Mudambi 2008).

\subsubsection{Characteristics of business models in Eastern Europe}

Similar analyses to those in the previous section were performed on the sample of Eastern European manufacturers. The results are summarised in Figure 4 and Appendix $B$.

In respect of upstream and downstream position measures, the following order was established:

$$
\begin{gathered}
\text { Upstream position: } \mathrm{CDM}<\mathrm{DM}<\mathrm{UM}=\mathrm{UP} \\
\text { Downstream position: } \mathrm{UM}=\mathrm{UP}<\mathrm{DM}=\mathrm{CDM}
\end{gathered}
$$

As in case of Western European companies, CDM firms in Eastern Europe have largely outsourced their upstream production processes, scoring very low on the upstream position indicator. However, contrary to Western Europe, UM and UP firms score almost the same in respect of downstream position: they both perform mainly upstream activities, playing the role of suppliers of materials, parts, and subassemblies to other manufacturers. DM firms are generally positioned in the downstream part of the supply chain, but - contrary to Western Europe - they also score relatively high on the upstream position indicator, controlling a large part of supply chain activities. Vertical integration measures also support this idea.

Vertical integration: $\mathrm{DM}>\mathrm{UM}=\mathrm{UP}=\mathrm{CDM}$

Companies that offer customer-related services (UP, CDM) also offer higher levels of product-related services.

$$
\text { Product-related services: } \mathrm{UM}=\mathrm{DM}<\mathrm{UP}=\mathrm{CDM}
$$

This finding again supports the idea that in order to offer advanced customerrelated services, manufacturing firms have to first gain experience in offering product-related services (Oliva - Kallenberg 2003; Gebauer et al. 2005). Additionally, similarly to the Western European case, product- and customer-related 


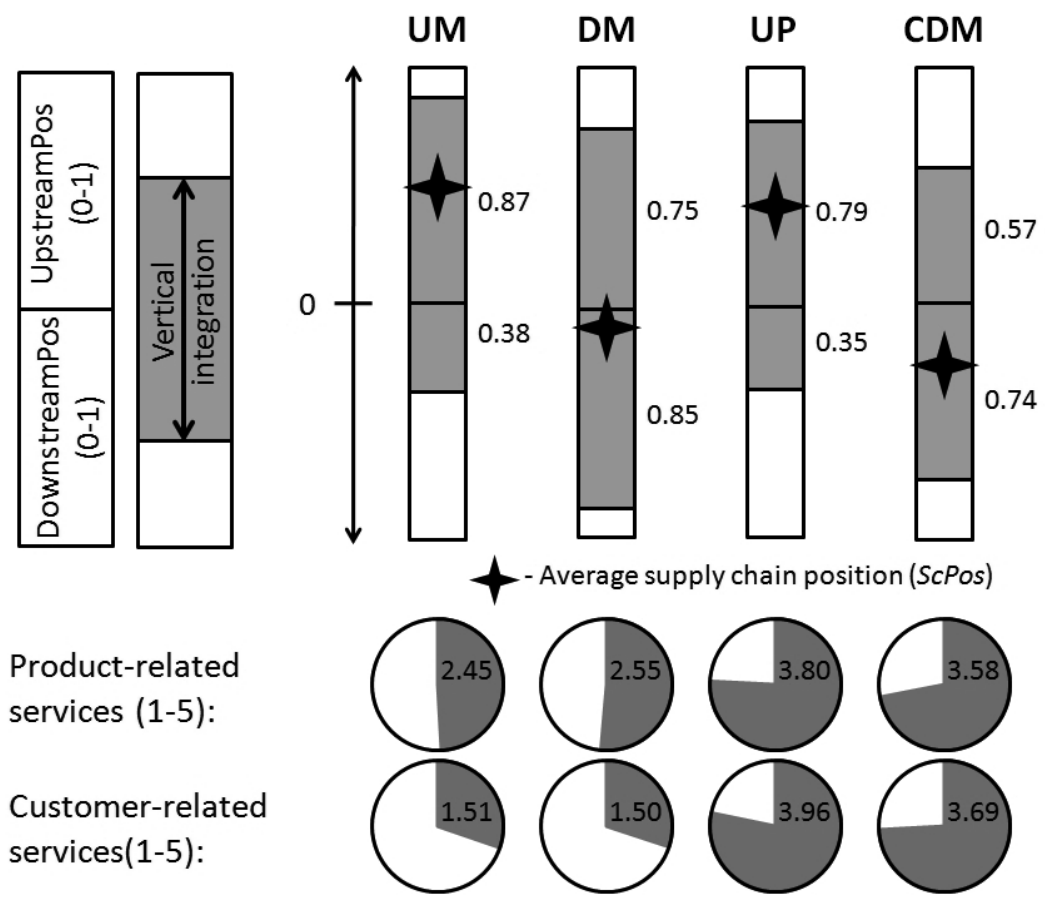

Figure 4. The main characteristics of Eastern European business models

services can create additional value in both upstream (UP) and downstream (CDM) supply chain positions (Lay et al. 2010).

In Eastern Europe, low-cost labour plays an equally important role in the location advantages of each category. Access to low-cost material seems to be more important for UP and DM groups than for UM firms, while proximity to suppliers and customers is more important for UP than for UM firms. This latter result is in concordance with case study findings that in order to offer integrated solutions for customers, including customer-related services, manufacturers (UP model) have to develop close cooperation with both customers (Davies 2004; Datta Roy 2011) and suppliers (Davies 2004; Davies et al. 2006).

In respect of business performances, there is a significant difference only between UM and UP firms. UM firms were able to increase their profitability (ROS) more intensively in the last 3 years compared to UP firms. This suggests that firms which are typical outsourcing targets in the region were able to increase their performance by performing well-focused upstream production processes. 


\subsubsection{Comparison of business models in Western and Eastern Europe}

After identifying the main characteristics of business models in Western and Eastern Europe, we provide a comparative description of them in Table 6 (detailed results can be found in Appendix B). A general difference is that low cost labour is a more important location factor for each business model in Eastern Europe than in Western Europe. These differences support the idea of a new division of labour discussed in internationalisation studies (Marin 2006; Mudambi 2008), where Eastern Europe is chosen for its low-cost factors, rather than for acquiring new knowledge (Yang et al. 2008).

\section{Table 6}

The main features of business models in Western and Eastern Europe

\begin{tabular}{ll}
\hline Western Europe & Eastern Europe \\
\hline Upstream Manufacturer (UM): & Upstream Manufacturer (UM): \\
- extremely focused, niche manufacturer & - focused manufacturer \\
- positioned highly upstream in the SC & - positioned highly upstream in the SC \\
- very few downstream activities & - few downstream activities performed \\
- low level of product-related services & - low level of product-related services \\
- low level of customer-related services & - low level of customer-related services \\
& - typical offshore targets (due to low costs) \\
\hline Downstream Manufacturer (DM): & Downstream Manufacturer (DM): \\
- upstream production outsourced & - upstream positions are relatively high \\
- high downstream position in the SC & - high downstream position in the SC \\
- lower vertical integration than in Eastern & - vertically integrated, large manufacturing \\
Europe & companies \\
- focuses exclusively on manufacturing & - focuses exclusively on manufacturing \\
- limited offering of services & - limited offering of services \\
- business performance is higher than that of & - lower market share relative to competitors \\
upstream players & than in Western Europe \\
\hline Upstream Partner (UP): & Upstream Partner (UP): \\
- upstream positioned manufacturer & - upstream positioned manufacturers \\
- offers both product- and customer-focused & - offers both product- and customer-focused \\
services & services \\
- services are mostly offered to industrial & - services are mostly offered to industrial \\
partners & partners \\
- achieve higher ROS improvement than in & \\
Eastern Europe & \\
\hline Customer-focused Downstream Manufacturer & Customer-focused Downstream Manufacturer \\
(CDM): & (CDM): \\
- a large part of upstream activities is out- & - a large part of upstream activities is out- \\
sourced & sourced \\
- higher focus on downstream activities & - higher focus on downstream activities \\
- offer a complete portfolio of product-related & - offer a complete portfolio of product-related \\
and customer-focused services & and customer-focused services \\
- competitive priorities are shifted away from & - the most untypical business model in Eastern \\
low-cost factors & Europe \\
\hline
\end{tabular}


However, our data indicates that upstream production activities are offshored and outsourced to Eastern Europe not only because of cheap labour, but also because in Western Europe return on sales generated by upstream processes is lower than that of downstream activities. Even if Western European companies decide to keep upstream processes in their home countries, they can only increase their competitiveness against Eastern European players if they move toward the UP business model, providing both product- and customer-related services. Although it provides lower return on sales than downstream positions in Western Europe, it is still higher than offering complete portfolio services as UP in Eastern Europe, which supports the literature: in developed countries, higher business performances can be achieved if a company moves towards offering high value-adding services to its customers (Mudambi 2008; Wise - Baumgartner 1999).

An important difference between Western and Eastern Europe is the level of vertical integration (see Appendix B, comparison of DM model). There is some explanation for this fact. One is the lack of trust between partners, which can be explained by historical reasons in the Eastern European post-socialist countries (Humphrey - Schmitz 1998). Another reason for the high vertical integration in Eastern Europe can be the lack of knowledge and openness towards new business models, which prevents companies from changing their old structures. Organisational changes represent one type of innovation (Schumpeter 1934) and the level of innovation continues to be relatively low in post-socialist countries (Kornai 2010).

The UM model seems to have its well-grounded place in both European regions. In Western Europe, it represents a very specialised, niche manufacturer that concentrates only on a well-defined, narrow set of production activities. A similar business model exists in Eastern Europe, but with a higher emphasis on low-cost labour, representing the typical offshore targets of companies from developed countries.

The DM model has a low share in Western Europe, but being closer to the endconsumer seems to yield higher business performances than the upstream models. In Eastern Europe, the DM model has a totally different role. They are larger, vertically more integrated manufacturers than in Western Europe. While they are still competitive in the Eastern European region, their market share is lower than of the same model in Western Europe.

The UP model has a similar role in both European regions. They are upstream manufacturers offering a complete set of services to their industrial partners. While low costs still play a crucial role in competing on the market for the Eastern European UP model, Western European UP companies can focus more efficiently on service-related issues, achieving a better improvement of profitability than their Eastern European counterparts. 
The CDM model is more representative for the Western European manufacturing, while it has only a limited share in the industry in Eastern Europe. In both regions, the CDM model focuses on downstream production coupled with a high intensity of offering a complete portfolio of services. The main difference is that in Western Europe, competitive priorities are not grounded on low-cost factors, which is in concordance with the servitisation literature (Correa et al. 2007; Gebauer - Fleisch 2007; Demeter - Szász 2013). However, in Eastern Europe, the CDM model still has to focus on low cost factors in order to remain competitive in the region.

\section{CONCLUSIONS}

\subsection{Summary and implications for theory}

Addressing the gap in quantitative research in the literature, our paper simultaneously investigated three issues: we addressed how (1) the supply chain position and (2) the level of servitisation of manufacturers is combined in (3) different macro-environments at different stages of economic development.

One general result is that, in contrast to the dominant model of large vertically integrated firms of the 20th century, European manufacturing companies currently seem to specialise and focus on a narrower set of supply chain activities, at least compared to Henry Ford's production model with a total control over the entire supply chain. This is in line with the international business literature, which argues that technological development has made it possible to "disaggregate business processes into progressively finer slices" (Mudambi 2008: 704), enabling firms to focus on increasingly narrow niches. However, our results also show that some vertically more integrated and some extremely specialised business models may coexist and produce similar business results.

Our results also indicate that services are offered both in the upstream and downstream positions of the supply chain. While the literature has generally focused on the downstream opportunities of service provision (Lay et al. 2010), our findings suggest that further research is needed to better understand the possibilities of upstream industrial service provision.

The paper also investigated how supply chain positions and servitisation levels are combined to create different business models in Western and Eastern Europe. According to internationalisation studies, the higher level of economic development of Western European countries implies a more extensive outsourcing/offshoring of upstream production processes. Our findings indicate that the dominant business model in Western Europe is a manufacturer positioned 
downstream in the supply chain, offering a complete portfolio of product- and customer-related services. In contrast, the upstream manufacturer with a very low intensity of service offering is more prevalent in Eastern Europe. On an aggregate level, Eastern European companies seem to assume the role of suppliers to Western European companies. Upstream processes are relocated to Eastern Europe mainly due to low cost reasons. Not being able to compete with the low costs of offshored production, upstream manufacturers seem to be less successful in Western Europe in terms of business performance.

While these business models seem to be the dominant trend, our results suggest that other business models can also successfully prevail. Indeed, it is an important finding of the paper that in both European regions, other combinations of supply chain position and servitisation can successfully compete with the dominant model. Business performance indicators involved in our study show little difference between the various business models, supporting the idea of the coexistence of different business models in both regions. Exceptions are the upstream production models in Western Europe, with a lower business performance compared to downstream manufacturing. However, this difference is captured only in the return on sales of companies, mainly due to the inability to produce at similar low costs as outsourced/offshored production. This result again supports the idea of a persistent low-cost motivation behind offshoring and outsourcing upstream production processes.

\subsection{Implications for practice and policy}

From a managerial perspective, the successful coexistence of business models with different degrees of vertical integration implies that despite the prevailing trend of business outsourcing, this is certainly not the only way to be successful. Downstream business models have a higher degree of vertical integration in both Eastern and Western Europe. Moreover, the servitisation literature suggests that in order to efficiently deliver services, companies should make a move downstream and integrate customers' processes (Wise - Baumgartner 1999; Oliva Kallenberg 2003; Davies 2004; Cohen et al. 2006). Actually, servitisation could become the driving force to start a new backwards cycle from extreme outsourcing towards higher vertical integration.

The diversity of business models in terms of supply chain position and servitisation shows that, again, company managers can choose from multiple business models. Despite the clear emergence of one particular dominant business model in both Eastern and Western Europe, business performance indicators suggest that not every company needs to follow the dominant trend. In Eastern Europe, 
beside the dominant upstream manufacturer model, downstream business models and the upstream servitised model yield a similar business performance. In Western Europe, downstream manufacturers have a similar performance as the dominant downstream servitised model.

In Western Europe, however, the two upstream business models seem to have a somewhat lower business performance, at least in respect of profitability (return on sales). The lower relative success of upstream business models implies that managers of these companies have basically two choices to improve their performance: 1) they either relocate their upstream processes to a developing region, or 2) make a move downstream and possibly increase the level of servitisation.

From an economic policy perspective, our results show that low costs seem to be still the most important reason for foreign investments in Eastern Europe. Even though policy makers prefer not to emphasise the low cost motivation, the findings of this paper indicate that due to low cost reasons, companies established in developing countries perform at least as well as companies in more developed countries. Consequently, this kind of division of labour between Western and Eastern Europe is advantageous for both parties and, thus, for the whole of Europe.

\subsection{Limitations and further research}

Beside the contribution to theory and practice, our study has its own limitations too. First, the analysis covered only some of the countries from the two regions (see Table 1). Moreover, it has to be also acknowledged that the research sample used in this study is not statistically representative, either on the country or on a European level. However, we argue that the careful definition of the targeted population (official databases of companies from the ISIC 28-35 industries in each country with more than 49 employees), the rigorous process of data collection (centrally coordinated data cleaning and validation procedure applied in each country, returning to companies to handle missing data), and the choice of regions as an aggregated unit of analysis can counterbalance to some extent the drawbacks of non-representativeness.

Second, our study used perceptual scales to measure performance. Using 5-point scales to assess performance, where each point on the scale stands for a wider interval of possibilities, represents an important shortcoming relative to objective performance measures. However, authors also argue that perceptual performance measures, while not providing the same level of precision as objective performance indicators, similarly satisfy the requirements of measurement reliability and validity (Ketokivi - Schroeder 2004). 
In respect of further research possibilities, as the costs in the Eastern European region inevitably follow an increasing tendency, it is an important question how the increasing costs will change the division of labour between the two European regions. Outsourcing/offshoring to Eastern Europe is still motivated by low costs. Catching up will most probably slow down this outsourcing/offshoring process, and a product portfolio matching customer requirements could become the key driver. Losing the "low cost region" status could mean losing the key attracting power of the Eastern European region, which will require developing new business models. For example, increasing the ratio of customer-related services within the service package, or developing the capability of managing partner relations seems to be a viable option for the future. However, as our results show, not every firm has to move in the same direction: outsourcing/offshoring production processes and establishing a focused manufacturing can be another viable option. The opportunities and the effective implementation of such business models represent a possible direction for future research.

This study was exploratory and limited to Europe. Other regions such as the American or Asian continent might also be included in further analyses to investigate whether our statements are valid at a more general level. There is a division of labour between North and South America as well as between Japan and China, for example. Some regional characteristics such as the size or development level of countries might lead to different combinations of supply chain positions and servitisation levels, which require further investigation. 


\section{APPENDIX A - QUESTIONNAIRE ITEMS}

\section{1) Supply chain position}

1. What is the percentage of spending on the following categories of goods purchased (your answers should add up to $100 \%$ )?

\begin{tabular}{rccc}
\hline Raw materials & Parts/components & Subassemblies/systems & Total \\
\hline$\%$ & $\%$ & $\%$ & $100 \%$ \\
\hline
\end{tabular}

2. Indicate the percentage of sales in the following categories of customers (your answers should add up to $100 \%$ ):

\begin{tabular}{rrrrrr}
\hline $\begin{array}{c}\text { Manufacturers of } \\
\text { subassemblies }\end{array}$ & $\begin{array}{c}\text { Manufacturers of } \\
\text { finished products }\end{array}$ & $\begin{array}{c}\text { Wholesalers / } \\
\text { distributors }\end{array}$ & End users & Total \\
\hline$\%$ & $\%$ & & $\%$ & & $100 \%$ \\
\hline
\end{tabular}

\section{2) Servitisation}

To what extent does your business unit/plant offer the following services alongside with the products?

\begin{tabular}{lccccc}
\hline & None & & & High \\
\hline Maintenance of products sold to customers & 1 & 2 & 3 & 4 & 5 \\
\hline Product upgrades (software, product modifications) & 1 & 2 & 3 & 4 & 5 \\
\hline Help desk/customer support centre & 1 & 2 & 3 & 4 & 5 \\
\hline Training in using the products & 1 & 2 & 3 & 4 & 5 \\
\hline Repairs & 1 & 2 & 3 & 4 & 5 \\
\hline Spare-parts & 1 & 2 & 3 & 4 & 5 \\
\hline
\end{tabular}

\section{3) Business performance}

What is the current business unit performance? For market share indicate average in market(s) served by the business unit.

\begin{tabular}{|c|c|c|c|c|c|c|c|c|c|c|}
\hline & \multicolumn{5}{|c|}{ Compared to three years ago the indicator has: } & \multirow{2}{*}{\multicolumn{5}{|c|}{$\begin{array}{l}\text { Relative to our main } \\
\text { competitor(s), } \\
\text { our performance is: }\end{array}$}} \\
\hline & \multirow{2}{*}{$\begin{array}{l}\text { deteriorated } \\
\text { more than } \\
5 \%\end{array}$} & \multirow{2}{*}{$\begin{array}{c}\text { stayed about } \\
\text { the same } \\
-5 \% /+5 \%\end{array}$} & \multirow[t]{2}{*}{$\begin{array}{l}\text { improved } \\
5 \%-15 \%\end{array}$} & \multirow[t]{2}{*}{$\begin{array}{l}\text { improved } \\
15 \%-25 \%\end{array}$} & \multirow{2}{*}{$\begin{array}{l}\text { improved } \\
\text { more than } \\
25 \%\end{array}$} & & & & & \\
\hline & & & & & & $\begin{array}{l}\mathrm{mu} \\
\text { wo }\end{array}$ & & equal & & $\begin{array}{l}\text { much } \\
\text { better }\end{array}$ \\
\hline Sales & 1 & 2 & 3 & 4 & 5 & 1 & 2 & 3 & 4 & 5 \\
\hline Market share & 1 & 2 & 3 & 4 & 5 & 1 & 2 & 3 & 4 & 5 \\
\hline $\begin{array}{l}\text { Return on sales } \\
(\text { ROS })^{1}\end{array}$ & 1 & 2 & 3 & 4 & 5 & 1 & 2 & 3 & 4 & 5 \\
\hline $\begin{array}{l}\text { Return on } \\
\text { investment } \\
(\mathrm{ROI})^{2}\end{array}$ & 1 & 2 & 3 & 4 & 5 & 1 & 2 & 3 & 4 & 5 \\
\hline
\end{tabular}

${ }^{1}$ ROS $=$ Earnings before interests and taxes $/$ Sales. ${ }^{2}$ ROI $=$ Earnings before interests and taxes $/$ Total assets. 


\section{4) Plant location}

What is the importance of the following advantages provided by the location of the plant?

\begin{tabular}{llllll}
\hline & \multicolumn{2}{c}{ None } & \multicolumn{2}{c}{ High } \\
\hline Proximity to suppliers & 1 & 2 & 3 & 4 & 5 \\
\hline Availability of low cost labour & 1 & 2 & 3 & 4 & 5 \\
\hline Availability of low cost material and/or energy sources & 1 & 2 & 3 & 4 & 5 \\
\hline Availability of skills and know-how & 1 & 2 & 3 & 4 & 5 \\
\hline Access to transportation \& logistic facilities & 1 & 2 & 3 & 4 & 5 \\
\hline Proximity to customers & 1 & 2 & 3 & 4 & 5 \\
\hline
\end{tabular}




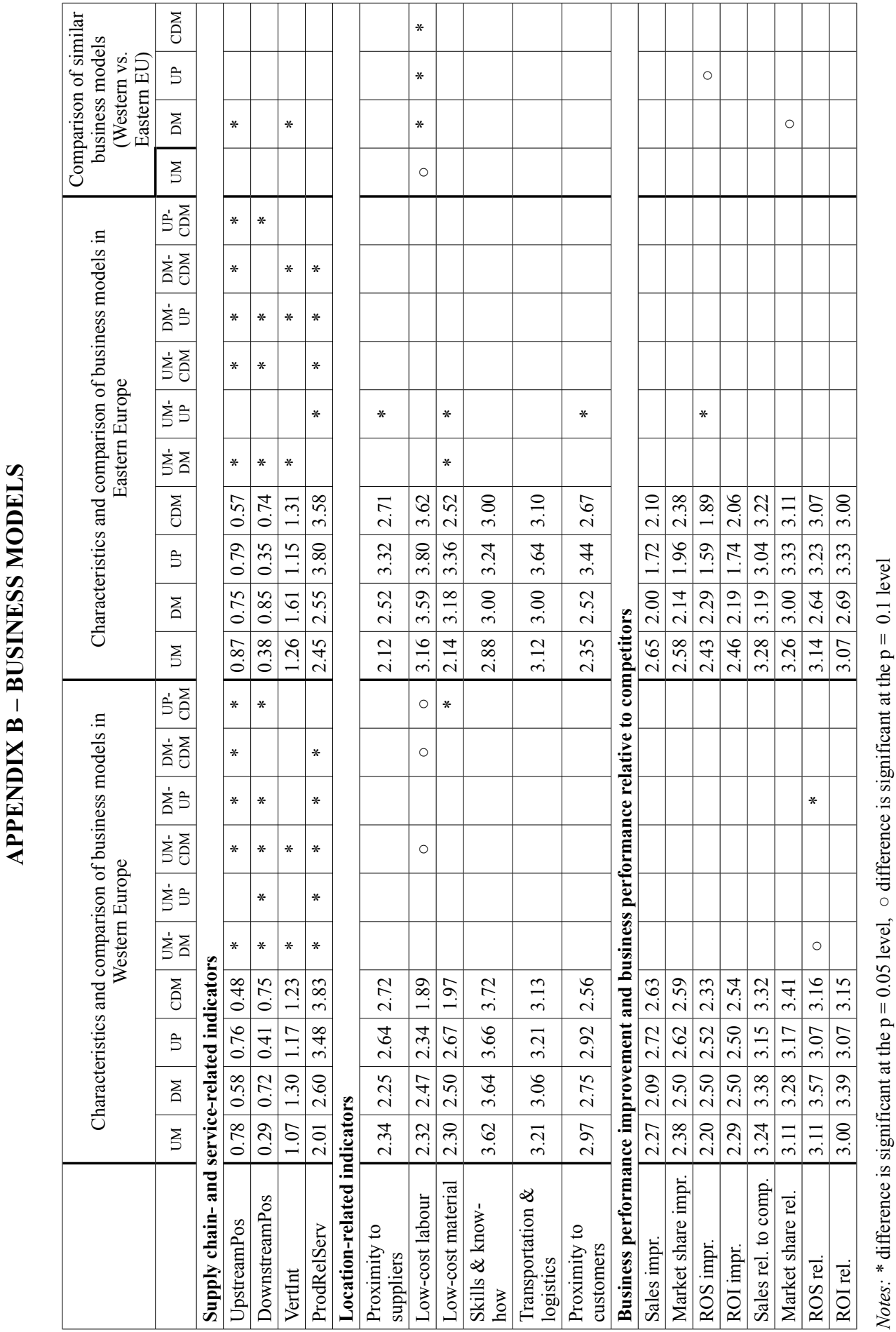




\section{REFERENCES}

Baines, T. - Lightfoot, H. - Benedettini, O. - Kay, J. (2009): The Servitization of Manufacturing. A Review of Literature and Reflection on Future Challenges. Journal of Manufacturing Technology Management, 20(5): 547-567.

Baines, T. - Lightfoot, H. - Smart, P. (2011): Servitization within Manufacturing. Exploring the Provision of Advanced Services and Their Impact on Vertical Integration. Journal of Manufacturing Technology Management, 22(7): 947-954.

Barkema, H. G. - Drogendijk, R. (2007): Internationalising in Small, Incremental or Larger Steps? Journal of International Business Studies, 38(1): 1-17.

Bikfalvi, A. - Lay, G. - Maloca, S. - Waser, B. R. (2013): Servitization and Networking: LargeScale Survey Findings on Product-Related Services. Service Business, 7(1): 61-82.

Cohen, M. A. - Agrawal, N. - Agrawal, V. (2006): Winning the Aftermarket. Harvard Business Review, May, 129-138.

Correa, H. L. - Ellram, L. M. - Scavarda, A. J. - Cooper, M. C. (2007): An Operations Management View of the Services and Goods Offering Mix. International Journal of Operations \& Production Management, 27(5): 444-463.

Dachs, B. - Ebersberger, B. - Kinkel, S. - Waser, B. R. (2006): Offshoring of Production - A European Perspective. Frequency, Target Regions and Motives. European Manufacturing Survey, Bulletin 2, Karlsruhe.

Davies, A. (2004): Moving Base into High-Value Integrated Solutions: A Value Stream Approach. Industrial and Corporate Change, 13(5): 727-756.

Davies, A. - Brady, T. - Hobday, M. (2006): Charting a Path toward Integrated Solution. MIT Sloan Management Review, 47(3): 39-48.

Demeter, K. - Szász, L. (2013): Towards Solution-Based Thinking: Characteristics of Servitization at Hungarian Manufacturing Companies. Journal of East European Management Studies, 18(3): 309-335.

Eckert, S. - Rossmeissl, F. (2005): Consequences of Convergence - Western Firms' FDI Activities in Central and Eastern Europe at the Dawning of EU-Enlargement. Journal of East European Management Studies, 10(1): 55-74.

Ferdows, K. (1997): Making the Most of Foreign Factories. Harvard Business Review, MarchApril, 73-88.

Filippov, S. - Duysters, G. (2011): Competence-Building in Foreign Subsidiaries: The Case of New EU Member States. Journal of East European Management Studies, 16(4): 286-314.

Frambach, R. - Wels-Lips, I. - Gündlach, A. (1997): Proactive Product Service Strategies - An Application in the European Health Market. Industrial Marketing Management, 26(4): 341-352.

Garmel, K. - Maliar, L. - Maliar, S. (2008): EU Eastern Enlargement and Foreign Investment: Implications from a Neoclassical Growth Model. Journal of Comparative Economics, 36(2): 307-325.

Gebauer, H. - Fleisch, E. (2007): An Investigation of the Relationship between Behavioural Processes, Motivation, Investments in the Service Business and Service Revenue. Industrial Marketing Management, 36(3): 337-348.

Gebauer, H. - Fleisch, E. - Friedli, T. (2005): Overcoming the Service Paradox in Manufacturing Industries. European Management Journal, 23(1): 14-26.

Humphrey, J. - Schmitz, H. (1998): Trust and Inter-Firm Relations in Developing and Transition Economies. The Journal of Development Studies, 34(4): 32-61.

Ketokivi, M. A. - Schroeder, R. G. (2004): Perceptual Measures of Performance: Fact or Fiction? Journal of Operations Management, 22(3): 247-264. 
Kinkel, S. (2012): Trends in Production Relocation and Backshoring Activities: Changing Patterns in the Course of the Global Economic Crisis. International Journal of Operations \& Production Management, 32(6): 696-720.

Kornai, J. (2010): Innovation and Dynamism. Economics of Transition, 18(4): 629-640.

Lay, G. - Copani, G. - Jäger, A. - Biege, S. (2010): The Relevance of Service in European Manufacturing Industries. Journal of Service Management, 21(5): 715-726.

Levy, D. L. (2005): Offshoring in the New Global Political Economy. Journal of Management Studies, 42(3): 685-693.

Marin, D. (2006): A New International Division of Labour in Europe: Outsourcing and Offshoring to Eastern Europe. Journal of the European Economic Association, 4(2-3): 612-622.

Melo, M. T. - Nickel, S. - Saldanha-Da-Gama, F. (2009): Facility Location and Supply Chain Management - A Review. European Journal of Operational Research, 196(2): 401-412.

Mudambi, R. (2008): Location, Control and Innovation in Knowledge Intensive Industries. Journal of Economic Geography, 8(5): 699-725.

Oliva, R. - Kallenberg, R. (2003): Managing the Transition from Products to Services. International Journal of Service Industry Management, 14(2): 160-172.

Poór, J. - Karoliny, Zs. - Musztyné Bártfai, B. V. - Pótó, Zs. - Farkas, F. (2009): Similarities and Differences of Human Resource Management in Private and Public Sector Organisations in the Light of New Public Management in International Comparison. Acta Oeconomica, 59(2): 179-206.

Quah, C.-H. (2014). Revisiting Business Cycles in the Eurozone: A Fuzzy Clustering and Discriminant Approach. Acta Oeconomica, 64(2): 161-180.

Ronen, S. - Shenkar, O. (1985): Clustering Countries on Attitudinal Dimensions: A Review and Synthesis. Academy of Management Review, 10(3): 435-454.

Schumpeter, J. A. (1934): The Theory of Economic Development. Cambridge: Harvard University Press.

Shi, Y. (2003): Internationalisation and Evolution of Manufacturing Systems: Classic Process Models, New Industrial Issues and Academic Challenges. Integrated Manufacturing Systems, 14(4): 357-368.

Sideri, S. (1997): Globalisation and Regional Integration. European Journal of Development Research, 9(1): 38-81.

Szász, L. - Demeter, K. (2011): Supply Chain Position and Servitization Efforts of Manufacturing Companies in Eastern and Western Europe. Journal of International Business and Economics, 11(1): 104-112.

UNCTAD (2013): World Investment Report 2013. New York and Geneva: United Nations.

Vandermerwe, S. - Rada, J. (1988): Servitization of Business: Adding Value by Adding Services. European Management Journal, 6(4): 314-324.

Wise, R. - Baumgartner, P. (1999): Go Downstream. The New Profit Imperative in Manufacturing. Harvard Business Review, September-October, 133-141.

Yang, Q. - Mudambi, R. - Meyer, K. E. (2008): Conventional and Reverse Knowledge Flows in Multinational Corporations. Journal of Management, 34(5): 882-902. 